\title{
Experimental Investigation of a Multicylinder Unmodified Diesel Engine Performance, Emission, and Heat Loss Characteristics Using Different Biodiesel Blends: Rollout of B10 in Malaysia
}

\author{
M. J. Abedin, ${ }^{1,2}$ H. H. Masjuki, ${ }^{1,2}$ M. A. Kalam, ${ }^{1,2}$ M. Varman, ${ }^{1,2}$ M. I. Arbab, ${ }^{1,2}$ \\ I. M. Rizwanul Fattah, ${ }^{1,2}$ and B. M. Masum ${ }^{1,2}$ \\ ${ }^{1}$ Centre for Energy Sciences, Faculty of Engineering, University of Malaya, 50603 Kuala Lumpur, Malaysia \\ ${ }^{2}$ Department of Mechanical Engineering, University of Malaya, 50603 Kuala Lumpur, Malaysia \\ Correspondence should be addressed to M. J. Abedin; joynul06me@yahoo.com and M. A. Kalam; kalam@um.edu.my
}

Received 22 January 2014; Revised 24 June 2014; Accepted 9 July 2014; Published 4 August 2014

Academic Editor: Shengping Wang

Copyright $\odot 2014$ M. J. Abedin et al. This is an open access article distributed under the Creative Commons Attribution License, which permits unrestricted use, distribution, and reproduction in any medium, provided the original work is properly cited.

\begin{abstract}
This paper deals with the performance and emission analysis of a multicylinder diesel engine using biodiesel along with an in-depth analysis of the engine heat losses in different subsystems followed by the energy balance of all the energy flows from the engine. Energy balance analysis allows the designer to appraise the internal energy variations of a thermodynamic system as a function of "energy flows" across the control volume as work or heat and also the enthalpies associated with the energy flows which are passing through these boundaries. Palm and coconut are the two most potential biodiesel feed stocks in this part of the world. The investigation was conducted in a four-cylinder diesel engine fuelled with $10 \%$ and $20 \%$ blends of palm and coconut biodiesels and compared with B5 at full load condition and in the speed range of 1000 to 4000 RPM. Among the all tested blends, palm blends seemed more promising in terms of engine performance, emission, and heat losses. The influence of heat losses on engine performance and emission has been discussed thoroughly in this paper.
\end{abstract}

\section{Introduction}

The rising oil prices and concerns on the depletion of fossil fuel reserves have forced researchers to not only look into engine optimization, but also find alternative resources to tackle the energy crisis. Biodiesel has gained a growing interest as one of the most promising solutions. Its primary advantages are biodegradable, renewable, and carbon neutral and the fact that it does not produce hazardous toxic gases [1-3]. Another major advantage of biodiesels is that they can be used either pure or blended with fossil diesel fuel at any proportions and can be burnt in the existing diesel engines without any further modifications [4].

1.1. The Reasons for Choosing Only These Feed Stocks and Blends. The main (about 73\%) agricultural product of Malaysia is oilseeds, mostly palm oil. According to United
States Department of Agriculture (USDA), Malaysia is the world's second largest producer (32.7\%) and exporter (40\%) of palm oil behind Indonesia (production-53.3\% and export$49.5 \%$ ) [5]. One of the reasons for choosing palm and coconut oil is that they are abundant in this particular region. For example, rapeseed in European Nations and soybeans in USA are abundant. Countries like Malaysia, Indonesia, and Thailand, and so forth, have vast costal area with surplus palm oil and coconut oil. Besides, in terms of oil productivity these feed stocks are on the top [6].

Palm oil based B5 biodiesel first rolled out in central regions of Malaysia at June 1, 2011, and then nationwide in early 2013. B5 is now available at 247 BHPetrol stations in Kuala Lumpur and consumes 1.03 million litres of palm-oil biodiesel in each month, which saves nearly 12.4 million litres of fossil diesel fuel consumption per year [7]. According to Malaysian Plantation Industries and Commodities Minister, 
"B10 will be launched nationwide as soon as the new standard is established and will phase out B5." They are formulating action plans with the help of Malaysian Palm Oil Board, which includes engine performance, emission, thermodynamics, and tribology analysis of B10 or higher blending ratio as required by the Original Equipment Manufacturers, especially on engine warranty [8].

1.2. Literature Review. In a 6-cylinder diesel engine [9], at full load and constant (1500 RPM) speed using palm biodiesel, it was reported that the power is decreased by $2.5 \%$, the BTE is decreased by $0.48 \%$, and the BSFC is increased by $7.5 \%$. The article also reported lower CO (86.89), HC (14.29\%), and smoke (67.65\%) emission and higher $\mathrm{NO}_{x}(22.13 \%)$ emission compared to diesel fuel. In a four-cylinder diesel engine [10] at full load and different engine speeds for various palm biodiesel blends, the power is almost the same for $10 \%$ biodiesel and decreased with the increase of further blend ratio. They also reported lower BTE and higher (max. $11 \%)$ BSFC compared to diesel fuel. That article found lower $\mathrm{CO}, \mathrm{HC}$, and smoke emission and higher $\mathrm{NO}_{x}$ emission for palm blends. Another article [11] reported similar results for coconut biodiesel in a four-cylinder diesel engine under similar engine conditions. However, according to single cylinder diesel engine reports, the results are similar (lower BTE and higher BSFC) for palm $[12,13]$ and coconut $[14,15]$ biodiesels though a few exceptions were also found [16, 17]. Similar emission results were reported for single cylinder engines, but few researchers [18-20] reported slightly lower $\mathrm{NO}_{x}$ emission while operated on palm and coconut biodiesel. Almost all researchers reported that the lower calorific value, higher kinetic viscosity and density (which cause poor fuel spray and atomization) of biodiesels are responsible for lower brake power and higher BSFC.

Energy balancing was reported for biodiesel [21, 22]. But those are not comprehensive and mostly focused on other topics. They reported that all the heat losses except exhaust heat loss were higher while using biodiesels compared to diesel fuel. This was attributed to the promotion of better combustion of biodiesel fuels. The reason for lower exhaust heat loss was attributed to the lower concentration of $\mathrm{HC}$ and $\mathrm{CO}$ emission in the exhaust gas for biodiesel fuels and it decreases more with the increase of biodiesel percentage in the blends [21].

1.3. Objectives. The objectives of our experiment are to analyze the variations in engine performance and emissions as well as in heat loss characteristics when we go beyond 5\% biodiesel (B10 and B20) using palm and coconut biodiesel.

\section{Experimental Setup and Procedure}

The experiment was performed on a Mitsubishi-4D56 diesel engine. Engine test bed picture is provided in Figure 1 and a detailed engine specification is given in Table 1.

The engine was loaded with a water cooled passive eddy current dynamometer. Therefore the test bed was connected

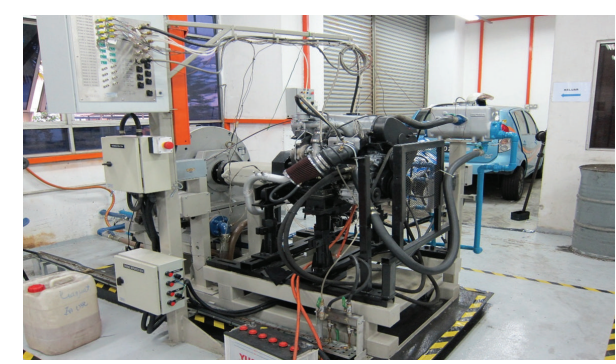

FIgURE 1: Picture of the engine test bed.

TABLE 1: Specification of the engine.

\begin{tabular}{lc}
\hline Parameter & Specification \\
\hline Engine type & In-line four cylinder \\
Bore & $91.1 \mathrm{~mm}$ \\
Stroke & $95.0 \mathrm{~mm}$ \\
Displacement & $2.5 \mathrm{~L}(2476 \mathrm{cc})$ \\
Compression ratio & $21: 1$ \\
Power & $55 \mathrm{~kW}$ at $4200 \mathrm{rpm}$ \\
Torque & $142 \mathrm{Nm}$ at $2500 \mathrm{rpm}$ \\
Fuel injection system & Common rail mechanically controlled \\
\hline
\end{tabular}

to the data acquisition board, which collects signal, rectify, filter, and convert the signal to the data to be read. The data acquisition board is connected to the laptop, where user can monitor, control, and analyze the data using software through REO-dCA controller. It provides full test sequence control with automatic and manual data logging options. The transducer box provides $16 \mathrm{~K} / \mathrm{J}$ thermocouple input channels, where we have used a total of $8 \mathrm{k}$-type thermocouples at 8 different locations to measure cooling water, lubricating oil, and exhaust temperatures. It also provides the facility of fuel flow, oil flow, and air flow measurements by using different pressure transducers. Rotameters have been used to measure engine cooling water flow.

In our experiment, we prepared four different biodiesel blends, that is, $10 \%$ and $20 \%$ of each biodiesel. The palm blends are presented as P10 and P20 and the coconut blends are presented as $\mathrm{C} 10$ and C20, respectively, where the numerical value denotes biodiesel percentage in the blend. The engine was operated at full throttle condition and varying speeds from 1000 to 4000 RPM at an interval of 500 RPM. Crude palm and coconut oil were provided by Forest Research Institute Malaysia (FRIM). B5 biodiesel was brought by the authors. The oils were converted to the biodiesels and properties have been measured in the authors' energy laboratory and engine tribology laboratory-1st floor, Department of mechanical Engineering, UM, $50603 \mathrm{KL}$, Malaysia. The measured fuel properties of all tested fuel blends are listed in Table 2 along with equipment specifications.

The exhaust emissions of our experiment were measured by using BOSCH (BEA-350) exhaust gas analyser. The specification of the analyser is provided in Table 3. 
TABLE 2: Measured fuel properties of all tested fuel blends.

\begin{tabular}{|c|c|c|c|c|c|c|c|}
\hline Properties & B5 & $\mathrm{P} 10$ & $\mathrm{P} 20$ & $\mathrm{C} 10$ & C20 & Testing equipment & $\begin{array}{c}\text { Test method and } \\
\text { specification limits }\end{array}$ \\
\hline Density at $15^{\circ} \mathrm{C}\left(\mathrm{kg} / \mathrm{m}^{3}\right)$ & 834.6 & 838 & 849.5 & 839.4 & 849.1 & $\begin{array}{l}\text { SVM } 3000 \text { (Anton Paar, } \\
\text { UK) }\end{array}$ & ASTM D4052 \\
\hline Calorific value $(\mathrm{MJ} / \mathrm{kg})$ & 43.4 & 40.5 & 40.1 & 38.2 & 36.8 & $\begin{array}{l}\text { C2000 basic calorimeter } \\
\text { (IKA, UK) }\end{array}$ & ASTM D240 \\
\hline Viscosity at $40^{\circ} \mathrm{C}(\mathrm{cSt})$ & 3.809 & 4.031 & 4.183 & 4.570 & 4.70 & $\begin{array}{l}\text { SVM } 3000 \text { (Anton Paar, } \\
\text { UK) }\end{array}$ & $\begin{array}{l}\text { ASTM D445 } \\
\quad(1.9-6.0)\end{array}$ \\
\hline Flash point $\left({ }^{\circ} \mathrm{C}\right)$ & 80.3 & 183.5 & 184 & 168.1 & 171.6 & $\begin{array}{l}\text { Pensky-Martens flash } \\
\text { point-automatic NPM } 440 \\
\text { (Norma Lab, France) }\end{array}$ & $\begin{array}{l}\text { ASTM D93 } \\
\left(>130^{\circ} \mathrm{C}\right)\end{array}$ \\
\hline
\end{tabular}

TABLE 3: Exhaust gas analyser specification.

\begin{tabular}{lcccc}
\hline Gas analyser & Emissions & Methods & Maximum limit & Accuracy \\
\hline & $\mathrm{CO}$ & Nondispersive infrared & $10 \%$ vol. & $\pm 0.001 \%$ vol. \\
BOSCH BEA-350 & $\mathrm{CO}_{2}$ & Nondispersive infrared & $18 \%$ vol. & $\pm 0.001 \%$ vol. \\
& $\mathrm{HC}$ & Flame ionization detector & $9999 \mathrm{ppm}$ & $\pm 1 \mathrm{ppm}$ \\
& $\mathrm{NO}_{x}$ & Electrochemical transmitter & $5000 \mathrm{ppm}$ & $\pm 1 \mathrm{ppm}$ \\
\hline
\end{tabular}

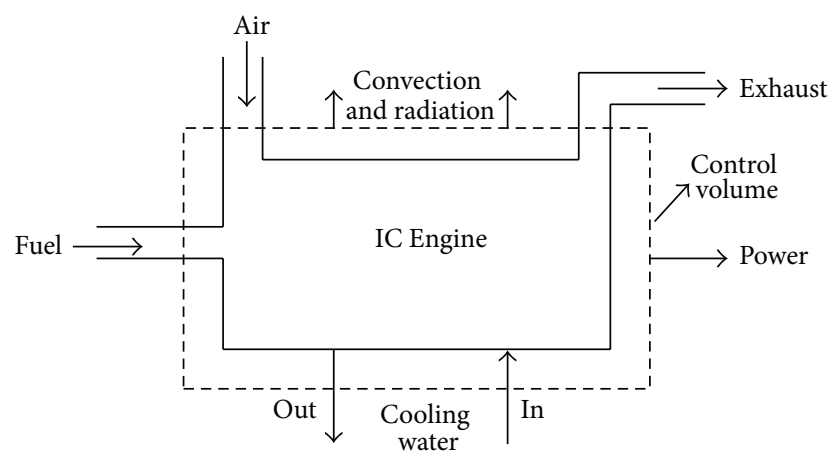

Figure 2: IC engine control volume showing energy flows [2].

\section{Theory of Heat Loss Calculation}

From Figure 2, if we consider the IC engine as a control volume (surrounded by control surface), then the energy flows from and to the engine can be expressed by the equations as follows.

The steady flow 1st law of thermodynamics for this control volume will be [23]

$$
Q_{s}=P_{b}+Q_{w}+Q_{\mathrm{oil}}+Q_{\mathrm{exh}}+Q_{\mathrm{un}}
$$

where $Q_{s}$ is the supplied fuel energy and is given by

$$
Q_{s}=\dot{m}_{f} \times Q_{\mathrm{LHV}},
$$

where $\dot{m}_{f}$ and $Q_{\mathrm{LHV}}$ are the mass flue rate and calorific value of the fuel, respectively.

The engine brake power $\left(P_{b}\right)$ can be computed by

$$
P_{b}=2 \times \pi \times N(\mathrm{rev} / \mathrm{s}) \times T(N \cdot m) \times 10^{-3},
$$

where $N$ and $T$ are the engine speed and torque, respectively.
The cooling water heat loss $\left(Q_{w}\right)$ can be calculated by using the following equation:

$$
Q_{w}=\dot{m}_{w} \times C_{w} \times \Delta T_{w}
$$

where $\dot{m}_{w}$ and $C_{w}$ are the mass flow rate and specific heat of water, respectively, and $\Delta T_{w}$ is the temperature difference between the cooling water inlet and outlet.

Now, if we can measure the required heat to increase the temperature of the total mass (air + fuel) from the outside air temperature $\left(T_{a}\right)$ to the exhaust gas temperature $\left(T_{g}\right)$, then we can compute the exhaust heat loss $\left(Q_{\text {exh }}\right)$ from the engine. The specific heat of air at mean exhaust gas temperature is assumed as the average specific heat $\left(C_{g}\right)$ of the exhaust gases for exhaust heat loss calculation [24]. So, the equation for exhaust heat loss calculation will be

$$
Q_{\mathrm{exh}}=\left(\dot{m}_{f}+\dot{m}_{a}\right) \times C_{g} \times\left(T_{g}-T_{a}\right)
$$

Like cooling water heat loss, the lubricating oil heat loss $\left(Q_{\text {oil }}\right)$ can be found by using

$$
Q_{\text {oil }}=\dot{m}_{\text {oil }} \times C_{\text {oil }} \times \Delta T_{\text {oil }} \text {, }
$$

where $m_{\text {oil }}$ and $C_{\text {oil }}$ are mass flow rate and specific heat of lubricating oil, respectively, and $\Delta T_{\text {oil }}$ is the temperature difference between the lubricating oil inlet and outlet. Finally, the unaccounted heat loss $\left(Q_{u n}\right)$ can be estimated by applying subtraction rule

$$
Q_{\mathrm{un}}=Q_{s}-\left(P_{b}+Q_{w}+Q_{\text {exh }}+Q_{\text {oil }}\right) .
$$

\section{Results and Discussion}

4.1. Performance Characteristics. This section will provide an in-depth analysis of the impact of biodiesel blends on engine brake power, fuel consumption, and thermal efficiency, at full load condition and varying engine speeds. 


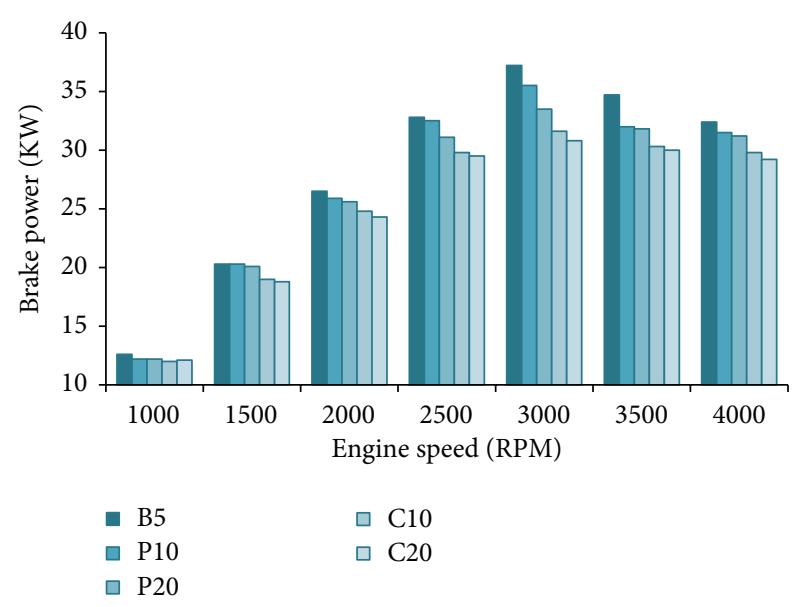

Figure 3: Brake power $\left(P_{b}\right)$ at full load.

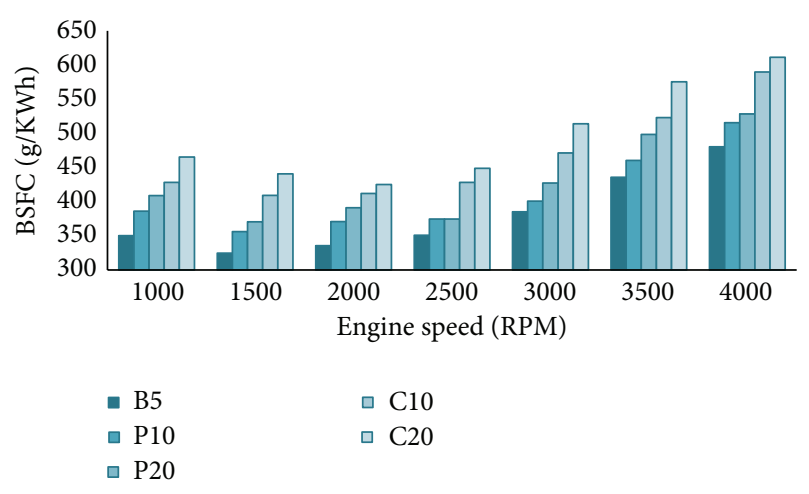

FIGURE 4: Variation of BSFC for all tested blends at 100\% load.

4.1.1. Engine Brake Power $\left(P_{b}\right)$. Figure 3 shows the variation of brake power $\left(P_{b}\right)$ of the tested biodiesel blends with varying engine speeds at $100 \%$ load. The brake power is increased steadily with increasing speeds to a maximum point for all fuel blends then falls down slightly at the end. B5 showed maximum brake power and palm blends showed close to B5 throughout the speed range. Coconut biodiesel has the lowest calorific value and the highest viscosity among the all blends. As expected, they showed poor performance comparing to others. Researchers $[3,25,26]$ attributed the reasons to the lower calorific value and higher viscosity of biodiesel blends. According to them, the excess oxygen content of biodiesels lowers their calorific values. Lower calorific value and higher viscosity cause uneven combustion hence lower brake power [27].

4.1.2. Brake Specific Fuel Consumption (BSFC). Figure 4 shows the nature of BSFC for all tested fuel blends with varying engine speeds. Fuel properties like density, viscosity, and calorific value clearly influence BSFC [28]. For example, lower calorific value means more fuel needs to be burned in the combustion chamber for the same power output. Again higher kinematic viscosity of biodiesels may cause

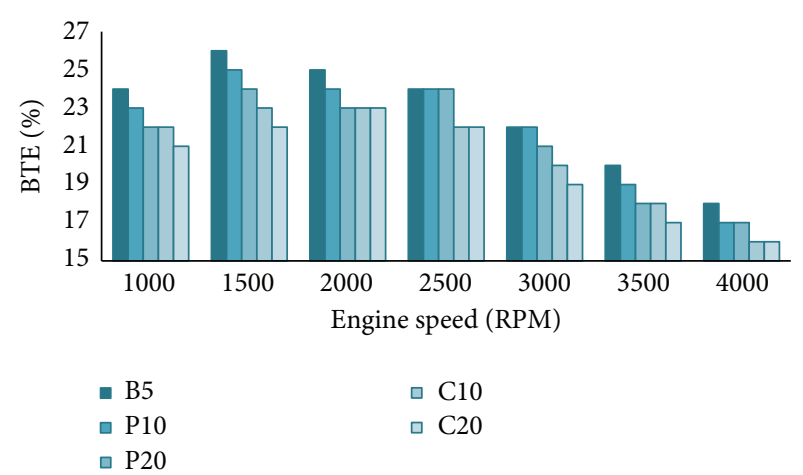

FIGURE 5: Brake thermal efficiency of all tested fuel blends at full load and various speeds.

poor atomization of the fuel, hence poor mixing with air and hence higher BSFC [29]. Clearly, the C10 and C20 blends exhibited highest BSFC throughout the speed range. B5 and palm blends showed lower BSFC compared to others which supports the given explanation. BSFC increased with the increase of biodiesel percentages in the blends. Similar results were found by other researchers $[3,18,25]$.

4.1.3. Brake Thermal Efficiency (BTE). Brake thermal efficiency appraises how efficiently an engine can transform the supplied fuel energy into useful work. Most of the supplied fuel energy will be loss as heat with the engine cooling water, lubricating oil, and exhaust gas [30]. This will be explained in detail in the heat loss section. For instance, we found that biodiesel increment increases engine frictional losses which dissipates through the engine coolant, cylinder walls, and so forth, which means lower BTE for biodiesel increment.

As expected BTE decreases with the increase of biodiesel percentage in the blends. BTE is inversely proportional to BSFC and fuel calorific value [4]. We already know that calorific value decreases and BSFC increases with increasing biodiesel percentage. But the BSFC increment is much more dominant here that is why BTE decreases for biodiesel increment despite the lower calorific value. From Figure 5, B5 showed highest BTE among all tested blends and P10 is close to it. At full load condition, fuel consumption increases with the increasing engine speed; hence the BTE decreases [30]. Most of the researchers $[4,10,12,14,29]$ reported similar results but a few researchers $[16,31]$ found reverse trend. The reason for higher BTE was attributed to the better combustion of oxygen rich biodiesels [21].

4.2. Emission Characteristics. At present, the governments are much more concerned about environmental pollution. Besides, they have imposed strict emission regulations for automobiles. So, the emission analysis of biodiesels is very important before their practical implementation. In this section, the influence of biodiesel blend ratios and engine speeds on gaseous emissions like $\mathrm{CO}, \mathrm{HC}$, and $\mathrm{NO}_{x}$ will be explored. 


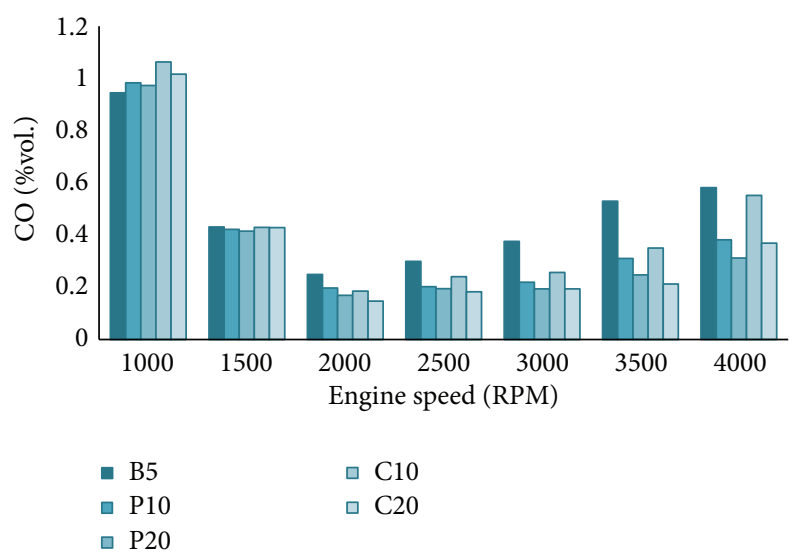

Figure 6: Carbon monoxide (CO) emission at full load.

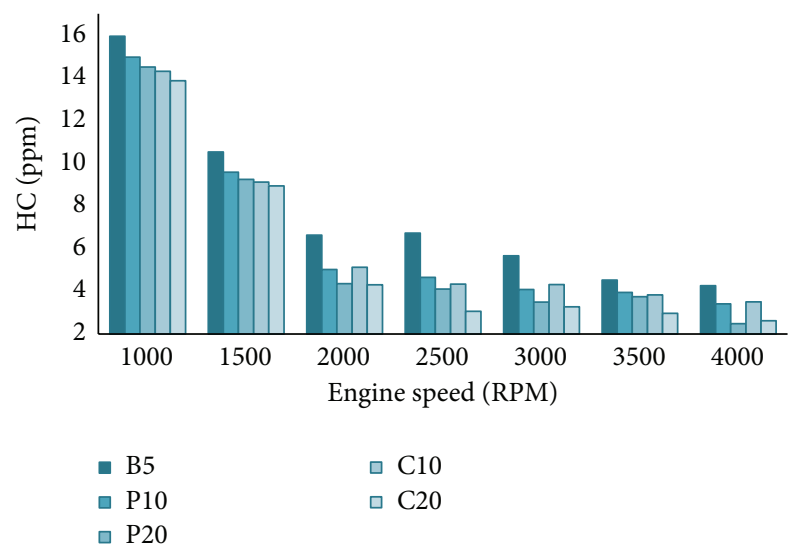

FIgURE 7: Hydrocarbon (HC) emission at 100\% load.

4.2.1. CO Emission. CO emission is decreased with the increase of biodiesel content in the blends especially at higher engine speeds. From Figure 6, CO emission of any $20 \%$ blend is lower than that of the $10 \%$ blend. The oxygen rich biodiesels result in more complete combustion of the blends which helps to convert $\mathrm{CO}$ into $\mathrm{CO}_{2}[3,32]$. At higher engine speeds, the in-cylinder combustion temperature is high which results in more complete combustion. So, the trend is more dominant at higher engine speeds. At lower engine speeds, the higher kinematic viscosity of biodiesel predominates the combustion process which results in comparatively higher CO emission [30]. C20 blend showed lowest CO emission among the all tested blends. It can be attributed to the higher oxygen content of coconut biodiesel compared to others [18].

4.2.2. HC Emission. Figure 7 shows the variations of $\mathrm{HC}$ emission for all the tested blends. The nature of $\mathrm{HC}$ emission is similar to $\mathrm{CO}$ emission. Here also the higher oxygen content of biodiesel is attributed for lower HC emission [4]. At lower engine speeds, the emission rate is high for all fuel blends but, at higher engine speeds, the trend is very much clear. According to Rahman et al. [4], higher engine speed ensures better mixing of fuel and air hence better combustion.

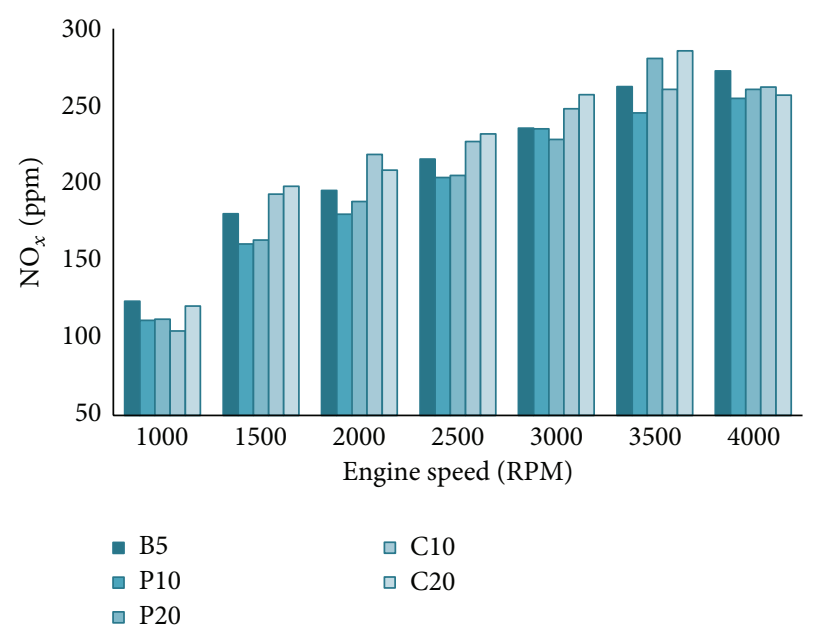

FIgURE 8: $\mathrm{NO}_{x}$ emission characteristics of all tested fuel blends at $100 \%$ load.

And again, the $20 \%$ blends showed lower HC emission than the $10 \%$ blends and B5, throughout the whole speed range. Here again, the $\mathrm{C} 20$ blend showed lowest $\mathrm{HC}$ emission among the all tested blends.

4.2.3. $\mathrm{NO}_{x}$ Emission. $\mathrm{NO}_{x}$ forms by the chain reactions involving $\mathrm{O}_{2}$ and $\mathrm{N}_{2}$ with the presence of sufficient temperature. So, the oxygen concentration and surrounding temperature are the key influence factors for $\mathrm{NO}_{x}$ emission. However, the engine load, speed, combustion chamber contents, homogeneity, and mixture density also have significant effects on $\mathrm{NO}_{x}$ emissions [33]. The general idea of $\mathrm{NO}_{x}$ emission is that it increases when the in-cylinder temperature is high. So, the high concentration of oxygen molecule in biodiesel promotes better combustion and hence higher $\mathrm{NO}_{x}$ emission. Again, the cetane number and viscosity also have influence on $\mathrm{NO}_{x}$ emission. Biodiesels exhibit higher cetane number and viscosity than the diesel fuel. Increment of biodiesel percentage in blends increases the cetane number and viscosity of the blends [3]. Higher cetane number leads to shorter ignition delay which allows the fuel-air mixture and the initial combustion products to have a longer residence time at elevated temperature and hence increases the thermal $\mathrm{NO}_{x}$ formation [4]. Kalam et al. [34] explained that the higher viscosity leads to a bigger droplet size and shorter ignition delay period which eventually increases $\mathrm{NO}_{x}$ emission. The combustion process improves when the speed increases due to more homogenous mixture of fuel and air. So, the $\mathrm{NO}_{x}$ emission increases with the increase of engine speed. From Figure 8, it can be said that $\mathrm{NO}_{x}$ emission increases with biodiesel blend ratio and engine speed. Palm blends (P10 and P20) have shown lower $\mathrm{NO}_{x}$ emission compared to other blends. It may happen due to the lower viscosity of palm blends compared to coconut blends. Most of the researchers reported similar trends of $\mathrm{CO}, \mathrm{HC}$, and $\mathrm{NO}_{x}$ emission in both single cylinder and multicylinder engine at similar engine conditions like ours. 


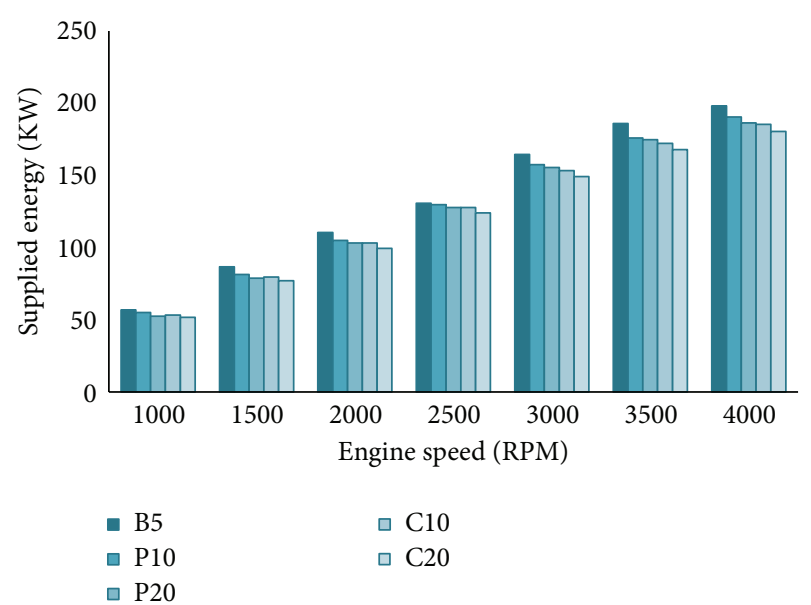

Figure 9: Supplied fuel energy variation.

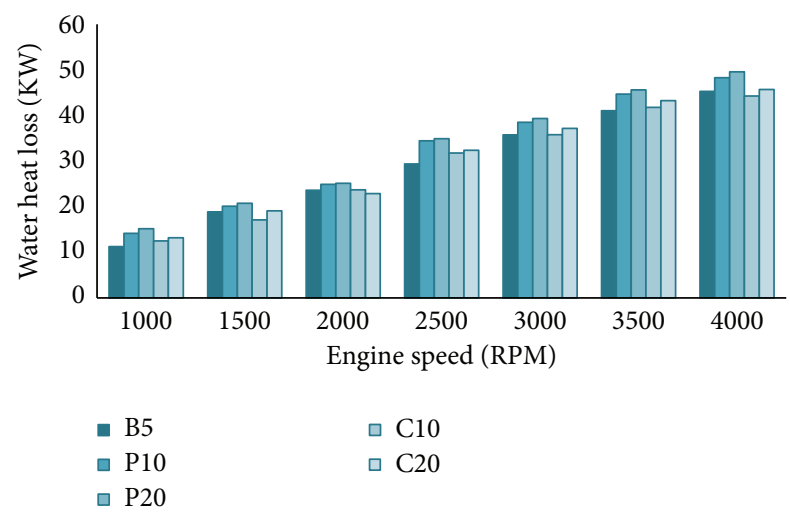

Figure 10: Water heat loss $\left(Q_{w}\right)$ variation at $100 \%$ load.

\subsection{Heat Loss Analysis}

4.3.1. Supplied Fuel Energy $\left(Q_{s}\right)$. Supplied fuel energy of all the tested blends are given in Figure 9. The supplied fuel energy $\left(Q_{s}\right)$ is the amount of fuel entering into the combustion chamber of an engine multiplied by its calorific value. Biodiesels have higher density and lower calorific value compared to fossil diesel [3]. The mass flow rate is higher for all blends, but the volume flow rate is the same since it is controlled by the fuel injector. Biodiesel increment lowers the supplied fuel energy of the blends as it lowers the calorific value [21]. The supplied fuel energy for B5 is the highest since its calorific value is the highest among the all tested blends. As the speed increases, more fuel is required to burn in the combustion chamber which means supplied fuel energy increases with increasing speed.

4.3.2. Water Heat Loss $\left(Q_{w}\right)$ and Lubricating Oil Heat Loss $\left(Q_{o i l}\right)$. From Figures 10 and 11, both the water heat loss $\left(Q_{w}\right)$ and the lubricating oil heat loss $\left(Q_{\text {oil }}\right)$ are higher when biodiesel percentage increased in the blends at all RPMs. As explained earlier, biodiesel promotes better fuel combustion; hence the in-cylinder combustion temperature, pressure, and

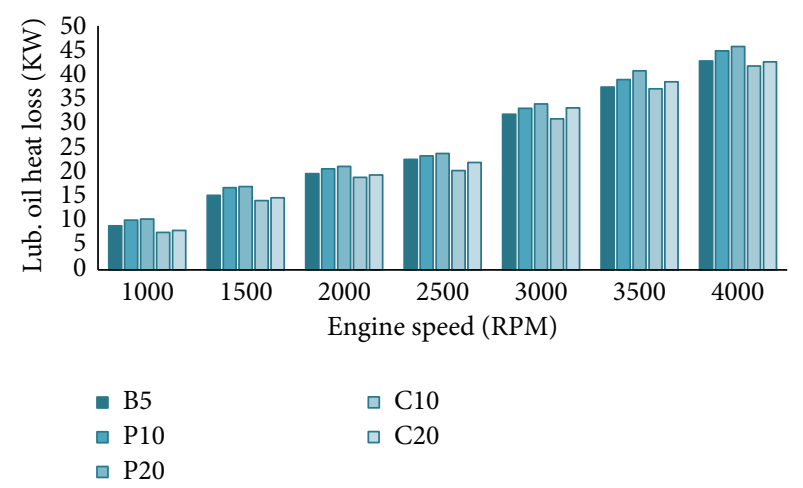

FIGURE 11: Lubricating oil heat loss $\left(Q_{\text {oil }}\right)$ for all tested blends at full load.

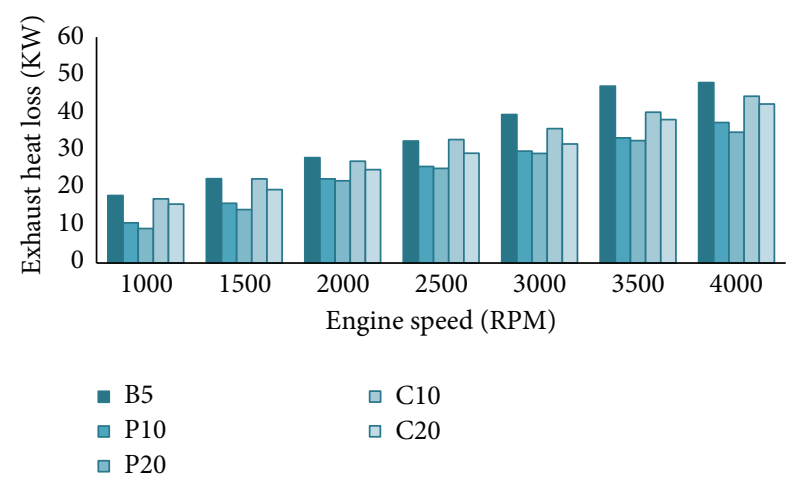

FIgURE 12: Exhaust heat loss $\left(Q_{\text {exh }}\right)$ at full load.

heat release rate are higher when the engine is running on biodiesels. So, the water heat loss and the lubricating oil heat loss increase about $1-3 \%$ and $1-2 \%$, respectively, for $5 \%$ biodiesel increment in the blends. This will be clearer in the energy balance section. This trend of heat loss is supported by other researcher's results $[22,35]$. We already know that with the increase of engine speed both the supplied fuel energy and the brake power increase. Similarly, all the heat losses also increase with engine speed, but the increment is not the same for all heat losses. Both heat losses are slightly higher for palm blends compared to other blends. It indicates that palm blends have higher combustion efficiency hence higher brake power compared to other blends which we have seen in Figures 3 and 5. Despite the higher heat losses, the palm blends (P10 and P20) showed higher brake power because this extraheat losses will be recovered by lower exhaust heat loss and unaccounted heat loss which will be discussed in the next section. Some researchers $[2,21,33]$ have suggested providing ceramic insulation around the cylinder walls and head to reduce this two heat losses which eventually will increase the exhaust heat loss.

4.3.3. Exhaust Heat Loss $\left(Q_{\text {exh }}\right)$. From Figure 12, B5 exhibits highest exhaust heat loss $\left(Q_{\text {exh }}\right)$ compared to other blends. It is already seen in the emission section that the palm blends give lower emissions compared to others and here 


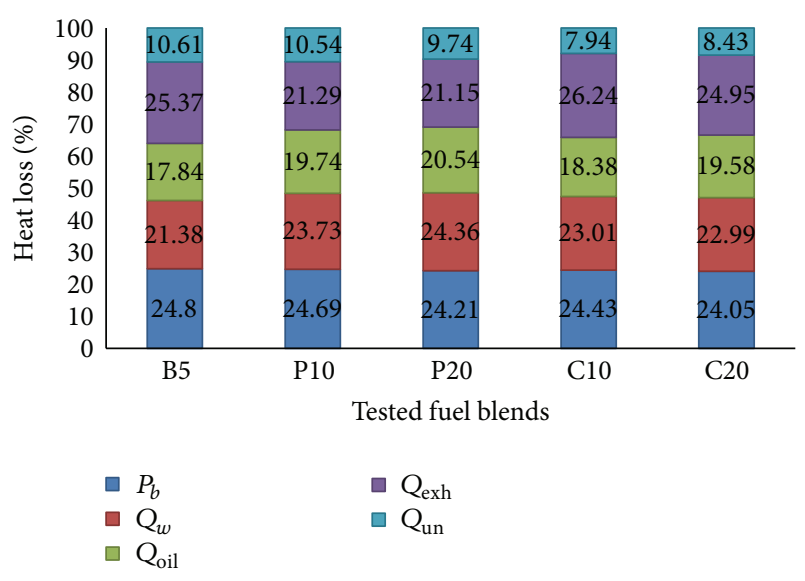

FIGURE 13: Engine energy balance at 2000 RPM and 100\% load.

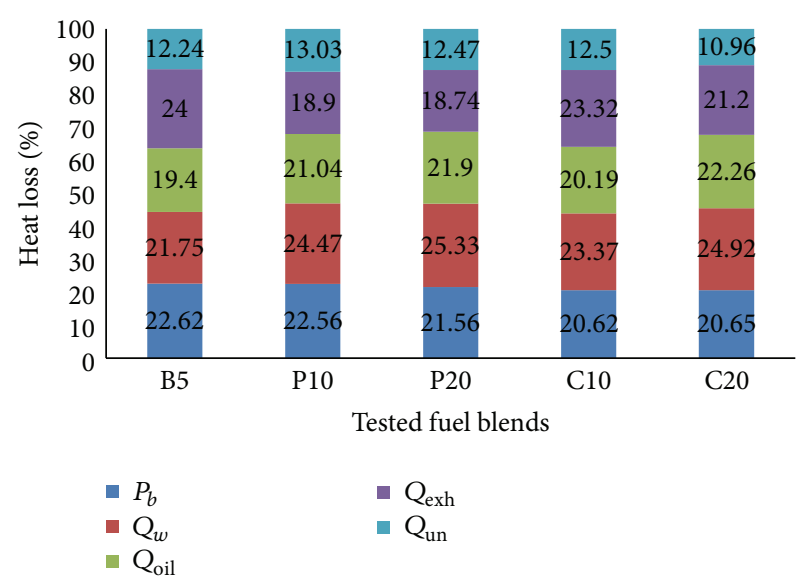

FIGURE 14: Engine energy balance at 3000 RPM and 100\% load.

they are showing lower exhaust heat loss. From the figure, it is also clear that biodiesel increment in the blends lowers exhaust heat loss. This trend of exhaust heat loss can also be explained from the exhaust gas temperature characteristics. Lower exhaust gas temperature signifies lower exhaust heat loss. We observed decreasing exhaust gas temperature trend with the increase of biodiesel percentage in our experiment. Similar trend of exhaust gas temperature was reported by the other researchers too $[4,27,30]$. The exhaust heat loss reduces by $0-2 \%$ when the biodiesel percentage increases in the blends from $10 \%$. This will be more clear from Figures 13 and 14.

Finally, the unaccounted heat loss $\left(Q_{\mathrm{un}}\right)$ is computed by subtracting the summation of all heat losses from the supplied fuel energy. It covers mostly the convection and radiation heat losses from the cylinder walls and also other unknown heat losses from the engine [2]. The trend of this heat loss is not definite. Similar results for unaccounted heat loss were presented by $[24,36]$.

4.3.4. Energy Balance. The energy balance has been shown for all tested fuel blends in Figures 13 and 14 at 2000 and 3000 RPM, respectively. The percentage of heat losses have been calculated by dividing the individual heat losses with supplied fuel energy. Each column displays the distribution of the percentages of supplied fuel energy as brake power and heat losses for a specific fuel blend. This approach will provide a clear picture of the heat losses from the engine. For example, when the engine is operated with $10 \%$ palm (P10) biodiesel at 2000 RPM, $24.69 \%$ of the supplied fuel energy is converted to useful work, $23.73 \%$ is lost with the cooling water, $19.74 \%$ is lost through the lubricating oil, $21.29 \%$ is lost with the exhaust gas, and the remaining $10.54 \%$ is unaccounted heat loss. Now, if we compare the results with P20 at 2000 RPM, the brake power is decreased by $0.5 \%$, the cooling water heat loss is increased by $0.63 \%$, the lubricating oil heat loss is increased by $0.8 \%$ while the exhaust heat loss is decreased by $0.15 \%$, and the unaccounted heat loss is decreased by $0.8 \%$. If we compare P10 at 2000 RPM with P10 at 3000 RPM, we will see that the cooling water and lubricating oil heat losses are increased while the exhaust heat loss is decreased as explained before. We can also see that palm blends have shown lower exhaust heat loss and hence higher brake power compared to coconut blends, at any RPM. It has been possible due to the much lower exhaust loss of palm blends despite the higher cooling water and lubricating oil heat losses compared to coconut blends.

\section{Conclusions}

The engine performance, emission, and heat loss analysis have been experimentally investigated using $10 \%$ and $20 \%$ blends of palm and coconut biodiesel in a multicylinder diesel engine. The theory of heat loss measurement, heat loss analysis, and a sample energy balance sheet showing the percentage of all heat losses have also been provided in this paper. However, based on our investigation, the following major conclusions have been drawn.

(1) B5 showed highest brake power and lowest BSFC throughout the entire speed range compared to other blends. This is also reflected in the BTE curves. Palm blends, especially the P10 blend, showed very much similar performance. Coconut blends (C10 and C20) are the poorest among the all blends in terms of engine performance.

(2) C20 blend showed lowest $\mathrm{CO}$ and $\mathrm{HC}$ emission whereas the palm blends (P10 and P20) showed almost similar result. In case of $\mathrm{NO}_{x}$ emission, the palm blends showed very good performance compared to other blends. With the increase of biodiesel percentage, $\mathrm{NO}_{x}$ emission increased for all tested fuel blends.

(3) Both the water heat loss and lubrication oil heat loss increased with the increase of blend ratio, whilst the exhaust heat loss decreased. Here, the palm blends (P10 and P20) showed higher water and lubricating oil heat loss but, again, they showed lower exhaust heat loss which recovered their higher losses and eventually showed good performance compared to coconut blends. 
At the end, we can say, if we go beyond B5, the brake power slightly falls but the $\mathrm{CO}$ and $\mathrm{HC}$ emissions improve a lot though the $\mathrm{NO}_{x}$ emission increases. Among the all tested blends, palm blends are more promising than others. If the higher water and lubricating oil heat losses of palm blends can be reduced by applying thermal barrier coatings (TBC) or ceramic coatings around the cylinder walls and head, then it may be possible to add a few KWs with the engine brake power.

\section{Nomenclature}

\author{
$C$ : Specific heat $(\mathrm{KJ} / \mathrm{Kg} \cdot \mathrm{K})$ \\ $\dot{m}$ : Mass flow rate $(\mathrm{Kg} / \mathrm{s})$ \\ $N$ : Engine speed (rev/s) \\ $P$ : Power (KW) \\ Q: Heat $(\mathrm{KJ})$ \\ $T$ : Temperature (K).
}

\section{Subscripts}

$\begin{array}{ll}a: & \text { Air } \\ b: & \text { Brake } \\ \text { cv: } & \text { Control volume } \\ \text { exh: } & \text { Exhaust } \\ f: & \text { Fuel } \\ g: & \text { Gas } \\ s: & \text { Supplied } \\ w: & \text { Water } \\ \text { un: } & \text { Unaccounted. }\end{array}$

\section{Abbreviations}

BSFC: Brake specific fuel consumption $(\mathrm{g} / \mathrm{KW} \cdot \mathrm{h})$

BTE: Brake thermal efficiency (\%)

B5: $\quad 5 \%$ palm biodiesel $+95 \%$ diesel

C10: $10 \%$ coconut biodiesel $+90 \%$ diesel

C20: $20 \%$ coconut biodiesel $+80 \%$ diesel

LPG: Liquid petroleum gas

LHV: Lower heating value $(\mathrm{KJ} / \mathrm{Kg})$

P10: $\quad 10 \%$ palm biodiesel $+90 \%$ Diesel

P20: $\quad 20 \%$ palm biodiesel $+80 \%$ Diesel

IC: Internal combustion

RPM: Revolution per minute.

\section{Conflict of Interests}

The authors declare that there is no conflict of interests regarding the publication of this paper.

\section{Acknowledgment}

The authors would like to appreciate University of Malaya for financial support through Research Grant no. RP016-2012E.

\section{References}

[1] M. J. Abedin, H. H. Masjuki, M. A. Kalam, A. Sanjid, S. M. A. Rahman, and B. M. Masum, "Energy balance of internal combustion engines using alternative fuels," Renewable and Sustainable Energy Reviews, vol. 26, pp. 20-33, 2013.

[2] M. Mofijur, H. H. Masjuki, M. A. Kalam, and A. E. Atabani, "Evaluation of biodiesel blending, engine performance and emissions characteristics of Jatropha curcas methyl ester: Malaysian perspective," Energy, vol. 55, pp. 879-887, 2013.

[3] B. M. Masum, M. A. Kalam, H. H. Masjuki, S. M. Palash, and I. M. Rizwanul Fattah, "Performance and emission analysis of a multi cylinder gasoline engine operating at different alcoholgasoline blends," RSC Advances, vol. 4, pp. 27898-27904, 2014.

[4] S. M. A. Rahman, H. H. Masjuki, M. A. Kalam, M. J. Abedin, A. Sanjid, and H. Sajjad, "Production of palm and Calophyllum inophyllum based biodiesel and investigation of blend performance and exhaust emission in an unmodified diesel engine at high idling conditions," Energy Conversion and Management, vol. 76, pp. 362-367, 2013.

[5] "United States Department of Agriculture (USDA). Palm Oil: World Supply and Distribution," http://apps.fas.usda.gov/psdonline/psdReport.aspx?hidReportRetrievalName $=$ Table+11\%3a + Palm+Oil\%3a+World+Supply+and+Distribution\&hidReport RetrievalID=710\&hidReportRetrievalTemplateID $=8$.

[6] H. C. Ong, T. M. I. Mahlia, H. H. Masjuki, and R. S. Norhasyima, "Comparison of palm oil, Jatropha curcas and Calophyllum inophyllum for biodiesel: a review," Renewable and Sustainable Energy Reviews, vol. 15, no. 8, pp. 3501-3515, 2011.

[7] Paultan.org, B5 biodiesel debuts in Kuala Lumpur, at 247 stations, http://paultan.org/2011/10/06/b5-biodiesel-debuts-inkuala-lumpur-at-247-stations/.

[8] Mysinchew.com. Malaysia set to implement B5 or B10 biodiesel scheme by mid-2014, 2013, http://www.mysinchew.com/node/ 82837.

[9] A. N. Ozsezen and M. Canakci, "Determination of performance and combustion characteristics of a diesel engine fueled with canola and waste palm oil methyl esters," Energy Conversion and Management, vol. 52, no. 1, pp. 108-116, 2011.

[10] M. Canakci, A. N. Ozsezen, E. Arcaklioglu, and A. Erdil, "Prediction of performance and exhaust emissions of a diesel engine fueled with biodiesel produced from waste frying palm oil," Expert Systems with Applications, vol. 36, no. 5, pp. 92689280, 2009.

[11] M. Han, K. Cho, C. Sluder, and R. Wagner, "Soybean and coconut biodiesel fuel effects on combustion characteristics in a light-duty diesel engine," SAE Technical Paper 2008-01-2501, 2008.

[12] H. Sharon, K. Karuppasamy, D. R. Soban Kumar, and A. Sundaresan, "A test on DI diesel engine fueled with methyl esters of used palm oil," Renewable Energy, vol. 47, pp. 160-166, 2012.

[13] P. Ndayishimiye and M. Tazerout, "Use of palm oil-based biofuel in the internal combustion engines: performance and emissions characteristics," Energy, vol. 36, no. 3, pp. 1790-1796, 2011.

[14] Y. Soma, M. Nakajima, K. Yoshida, H. Shoji, and A. Iijima, "The application of coconut-oil methyl ester for diesel engine," SAE Technical Paper 2007-32-0065, 2007.

[15] A. M. Liaquat, H. H. Masjuki, M. A. Kalam et al., "Effect of coconut biodiesel blended fuels on engine performance and emission characteristics," Procedia Engineering, vol. 56, pp. 583590, 2013.

[16] J. Huang, Y. Wang, J.-B. Qin, and A. P. Roskilly, "Comparative study of performance and emissions of a diesel engine using Chinese pistache and jatropha biodiesel," Fuel Processing Technology, vol. 91, no. 11, pp. 1761-1767, 2010. 
[17] P. Tan, Z. Hu, D. Lou, and Z. Li, "Exhaust emissions from a lightduty diesel engine with Jatropha biodiesel fuel," Energy, vol. 39, no. 1, pp. 356-362, 2012.

[18] E. Kinoshita, T. Myo, K. Hamasaki, and S. Nishi, "Combustion characteristics of diesel engine with coconut oil ethyl ester," SAE Technical Paper 2007-01-2021, 2007.

[19] J.-H. Ng, H. K. Ng, and S. Gan, "Characterisation of engineout responses from a light-duty diesel engine fuelled with palm methyl ester (PME)," Applied Energy, vol. 90, no. 1, pp. 58-67, 2012.

[20] E. Kinoshita, K. Hamasaki, and C. Jaqin, "Diesel combustion of palm oil methyl ester," SAE Technical Paper 2003-01-1929, 2003.

[21] M. Canakci and M. Hosoz, "Energy and exergy analyses of a diesel engine fuelled with various biodiesels," Energy Sources Part B, vol. 1, no. 4, pp. 379-394, 2006.

[22] B. K. Debnath, N. Sahoo, and U. K. Saha, "Thermodynamic analysis of a variable compression ratio diesel engine running with palm oil methyl ester," Energy Conversion and Management, vol. 65, pp. 147-154, 2013.

[23] J. B. Heywood, Internal Combustion Engine Fundamentals, McGraw-Hill, New York, NY, USA, 1988.

[24] H. Özcan and M. S. Söylemez, "Thermal balance of a LPG fuelled, four stroke SI engine with water addition," Energy Conversion and Management, vol. 47, no. 5, pp. 570-581, 2006.

[25] E. Buyukkaya, "Effects of biodiesel on a DI diesel engine performance, emission and combustion characteristics," Fuel, vol. 89, no. 10, pp. 3099-3105, 2010.

[26] P. K. Sahoo, L. M. Das, M. K. G. Babu et al., "Comparative evaluation of performance and emission characteristics of jatropha, karanja and polanga based biodiesel as fuel in a tractor engine," Fuel, vol. 88, no. 9, pp. 1698-1707, 2009.

[27] K. Muralidharan, D. Vasudevan, and K. N. Sheeba, "Performance, emission and combustion characteristics of biodiesel fuelled variable compression ratio engine," Energy, vol. 36, no. 8, pp. 5385-5393, 2011.

[28] D. H. Qi, H. Chen, L. M. Geng, and Y. Z. Bian, "Experimental studies on the combustion characteristics and performance of a direct injection engine fueled with biodiesel/diesel blends," Energy Conversion and Management, vol. 51, no. 12, pp. 29852992, 2010.

[29] T. Ganapathy, R. P. Gakkhar, and K. Murugesan, "Influence of injection timing on performance, combustion and emission characteristics of Jatropha biodiesel engine," Applied Energy, vol. 88, no. 12, pp. 4376-4386, 2011.

[30] H. An, W. M. Yang, S. K. Chou, and K. J. Chua, "Combustion and emissions characteristics of diesel engine fueled by biodiesel at partial load conditions," Applied Energy, vol. 99, pp. 363-371, 2012.

[31] M. Sundaresan, S. Chandrasekaran, and P. T. Porai, "Analysis of combustion, performance and emission characteristics of blends of methyl esters of jatropha oil (MEJ) in DI diesel engine," SAE Technical Paper 2007-32-0066, 2007.

[32] B. S. Chauhan, N. Kumar, and H. M. Cho, "A study on the performance and emission of a diesel engine fueled with Jatropha biodiesel oil and its blends," Energy, vol. 37, no. 1, pp. 616-622, 2012.

[33] B. M. Masum, M. A. Kalam, H. H. Masjuki, I. M. Rizwanul Fattah, S. M Palash, and M. J. Abedin, "Effect of ethanolgasoline blend on NOx emission in SI engine," Renewable and Sustainable Energy Reviews, vol. 24, pp. 209-222, 2013.
[34] M. A. Kalam, H. H. Masjuki, M. H. Jayed, and A. M. Liaquat, "Emission and performance characteristics of an indirect ignition diesel engine fuelled with waste cooking oil," Energy, vol. 36, no. 1, pp. 397-402, 2011.

[35] M. E. Tat, "Cetane number effect on the energetic and exergetic efficiency of a diesel engine fuelled with biodiesel," Fuel Processing Technology, vol. 92, no. 7, pp. 1311-1321, 2011.

[36] F. Yüksel and M. A. Ceviz, "Thermal balance of a four stroke SI engine operating on hydrogen as a supplementary fuel," Energy, vol. 28, no. 11, pp. 1069-1080, 2003. 


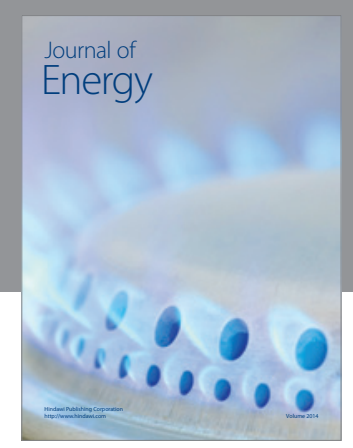

Journal of

Industrial Engineering
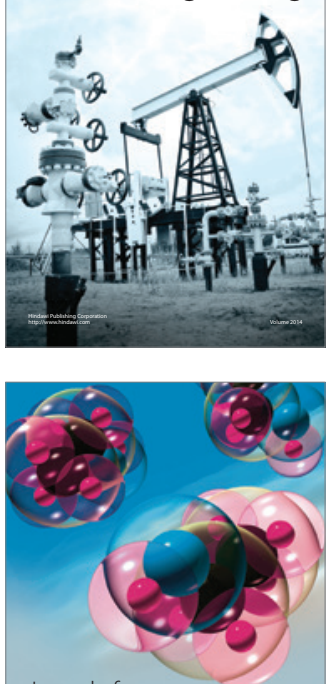

Fuels
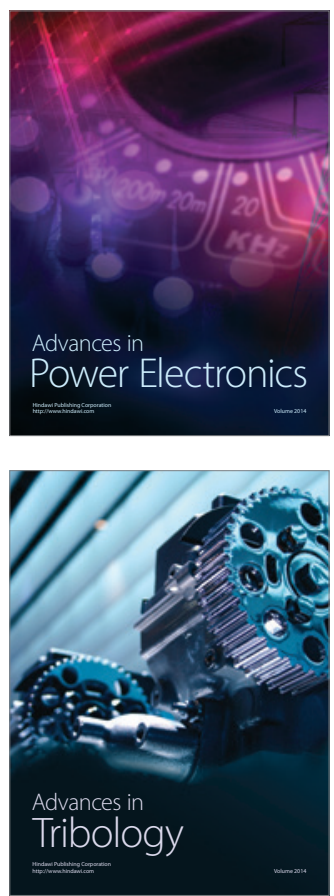

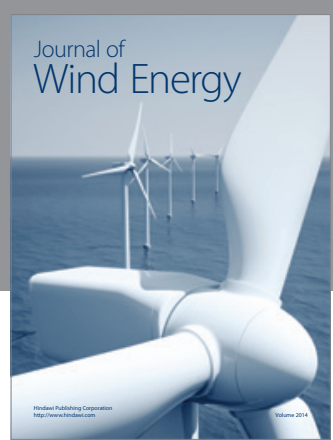

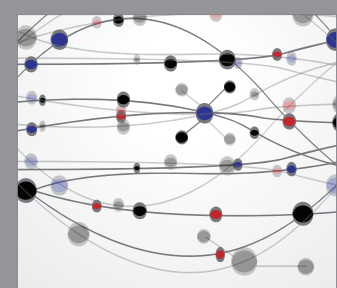

The Scientific World Journal

Submit your manuscripts at http://www.hindawi.com

Journal of

Structures
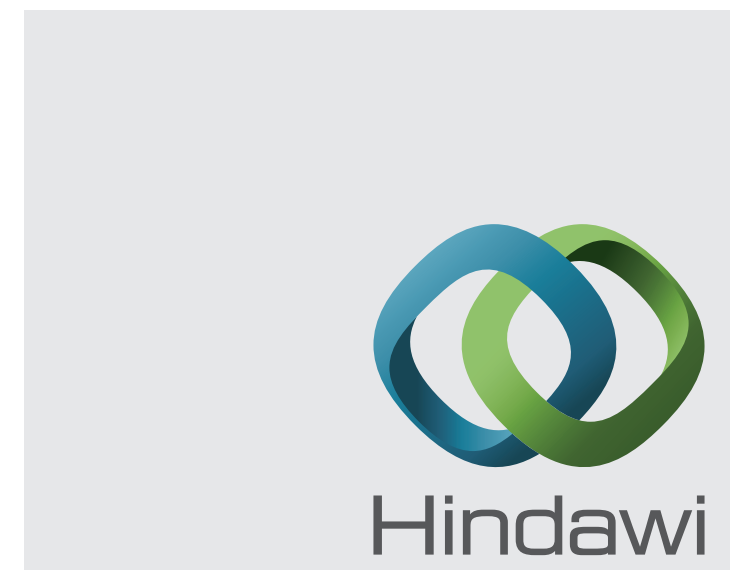

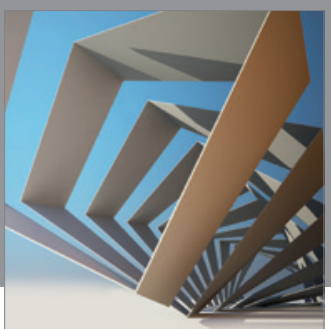

Rotating

Machinery
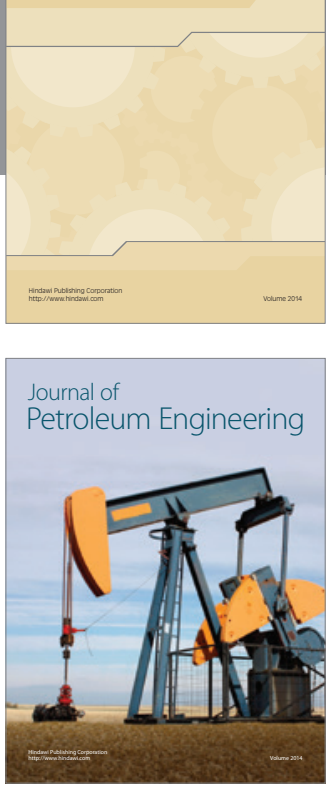

Journal of

Solar Energy
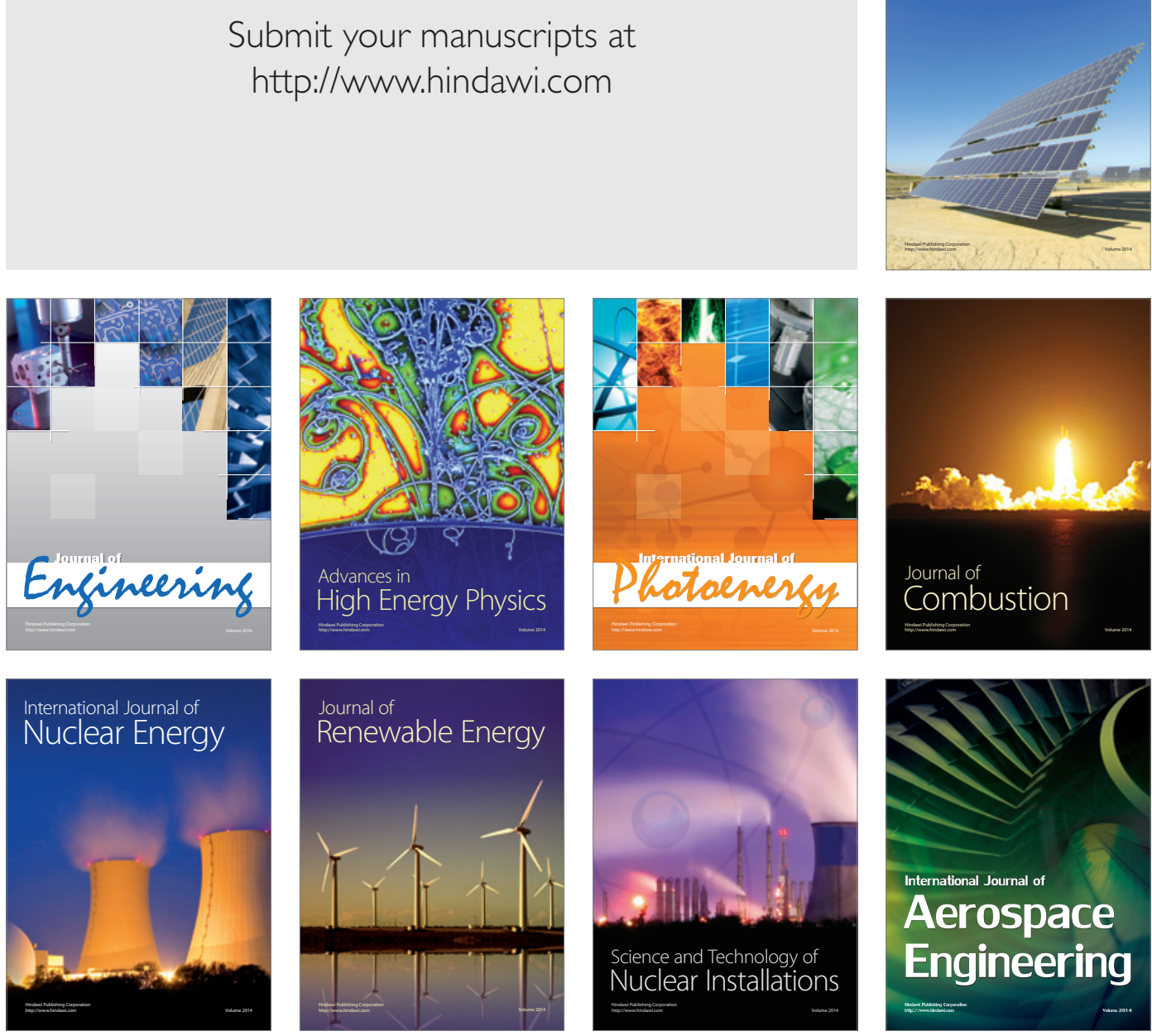